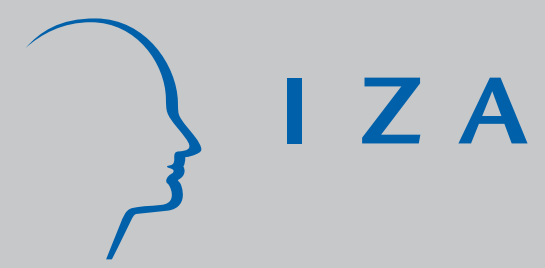

IZA DP No. 7618

A Web Survey Analysis of the Subjective Well-being of Spanish Workers

Martin Guzi

Pablo de Pedraza

September 2013

Forschungsinstitut zur Zukunft der Arbeit Institute for the Study of Labor 


\title{
A Web Survey Analysis of the Subjective Well-being of Spanish Workers
}

\author{
Martin Guzi \\ Masaryk University, \\ CELSI and IZA \\ Pablo de Pedraza \\ University of Salamanca

\section{Discussion Paper No. 7618 \\ September 2013} \\ IZA \\ P.O. Box 7240 \\ 53072 Bonn \\ Germany \\ Phone: +49-228-3894-0 \\ Fax: +49-228-3894-180 \\ E-mail: iza@iza.org
}

Any opinions expressed here are those of the author(s) and not those of IZA. Research published in this series may include views on policy, but the institute itself takes no institutional policy positions. The IZA research network is committed to the IZA Guiding Principles of Research Integrity.

The Institute for the Study of Labor (IZA) in Bonn is a local and virtual international research center and a place of communication between science, politics and business. IZA is an independent nonprofit organization supported by Deutsche Post Foundation. The center is associated with the University of Bonn and offers a stimulating research environment through its international network, workshops and conferences, data service, project support, research visits and doctoral program. IZA engages in (i) original and internationally competitive research in all fields of labor economics, (ii) development of policy concepts, and (iii) dissemination of research results and concepts to the interested public.

IZA Discussion Papers often represent preliminary work and are circulated to encourage discussion. Citation of such a paper should account for its provisional character. A revised version may be available directly from the author. 
IZA Discussion Paper No. 7618

September 2013

\section{ABSTRACT}

\section{A Web Survey Analysis of the Subjective Well-being of Spanish Workers ${ }^{1}$}

This paper makes use of a large sample of individual data obtained from web surveys in the Wagelndicator project. Data includes extensive information on the quality of working conditions together with different well-being indicators. The paper emphasizes the role of work-related characteristics as a specific and very important aspect of life. In our analysis, we demonstrate the role of working conditions in the following three domains: overall lifesatisfaction; satisfaction with one's job; and satisfaction with the combination of family and work. The paper also contributes to the ongoing debate on web survey data quality, reliability, and validity for scientific use. It demonstrates how social sciences can benefit from the use of web survey data in order to overcome the limits of traditional information sources.

JEL Classification: J28, J81

Keywords: $\quad$ subjective well-being, web-surveys, working conditions

Corresponding author:

Martin Guzi

Masaryk University

Department of Public Economics

Lipova 507/41a

60200 Brno

Czech Republic

E-mail: Martin.Guzi@econ.muni.cz

\footnotetext{
${ }^{1}$ This research was supported by the STSM Grant from the COST Action IS1004 and the programme "Employment of Best Young Scientists for International Cooperation Empowerment" (CZ.1.07/2.3.00/30.0037). We thank Kea Tijdens for her comments and suggestions. All errors existing in this text are the responsibility of the authors.
} 


\section{Introduction}

According to Frey and Stutzer (2010), the research of subjective well-being (SWB) should remain open to constructing different indicators for different aspects of life. The research on SWB, despite examining very broad areas, tends to explore the role of working conditions in job satisfaction models, but neglects the importance of work related variables in other domains of SWB. In developed countries, employed individuals spend on average one-third of their time each day at the workplace. Working conditions and preferences towards employment therefore constitute the most significant determinants of SWB, but the available evidence is scarce, particularly due to data availability. The relationship between different aspects of working conditions and SWB remains undiscovered also because traditional surveys are limited in the scope of the survey questionnaires and the number of questions related to working conditions is restricted. Moreover, surveys including well-being indicators typically do not permit SWB analysis at the country level, mainly due to the small sample sizes. ${ }^{2}$ Empirical studies mostly rely on samples by pooling observations of all available countries. Indicators obtained from cross-country analysis cannot adequately capture the wellbeing of an entire nation and therefore, findings have limited use in national policy making. This paper offers an alternative to those limits by making use of a large sample of individual data collected in the WageIndicator (WI) project. Data is obtained from web surveys ${ }^{3}$ and includes extensive information on the quality of working conditions together with several SWB indicators. The goal of the paper is twofold - applied and methodological. First, the paper emphasizes the role of work related characteristics as a specific and very important aspect of life. In our analysis, we demonstrate the role of working conditions in the different domains of SWB. Second, the paper contributes to the debate on web survey data quality, reliability, and validity for scientific use. It demonstrates how social sciences and SWB research can benefit from the use of web survey data in order to overcome the limits of traditional sources of information.

The paper is organized as follows. In Section 2, we discuss the advantages and disadvantages of data obtained from web surveys. We explain how the quality of data can be tested and we discuss methodological solutions. Section 3 presents the findings from SWB literature with a particular focus on the role of working conditions and the Spanish population. Section 4 introduces the data used in the analysis. In section 5, we discuss the role of individual characteristics and the quality of working conditions in the different domains of well-being. We confirm that results from the WI sample match remarkably well to those obtained from probabilistic surveys, especially after calibrating the WI sample using a propensity score weighting technique. We provide more evidence of data reliability and new conclusions on work related variables not widely presented in the SWB literature. Section 6 concludes our analysis.

\section{The advantages, disadvantages and solutions for web-survey data.}

Today, people are used to conducting many of their daily activities via the Internet. The use of online services and mobile devices has gained a lot of popularity. This behavior

\footnotetext{
${ }^{2}$ Few countries collect data in large numbers that are suitable for studying life-satisfaction determinants (e.g. Germany, United Kingdom, USA and Australia). International evidence often relies on the European Social Survey, Eurobarometer and the World Values Surveys (Leuchinger, Meier and Stutzer, 2010).

${ }^{3}$ In the text, we refer to the web surveys if the sample is obtained from questionnaires posted on Internet. Traditional surveys refer to surveys conducted by phone or face-to-face interviews in which participants are randomly selected.
} 
generates a lot of information, but also allows for a new channel of data collection. Reips (2006) defines the four methods of web data collection: non-reactive data collection; web-based experimenting; web-based testing; and web-surveying. In this paper, we exploit data obtained through a Continuous Voluntary Web Survey (CVWS). This type of web survey has become a very attractive tool as it allows access to respondents at a lower cost and larger numbers relative to traditional surveys that are conducted via phone, mail, or on a face-to-face basis. The analysis based on web survey data triggered a debate about the external validity of the findings. Both the strengths and weaknesses of web surveys have been discussed extensively in literature (e.g. Couper, 2000; Fricker and Schonlau, 2002; Groves, 2004; Honing and Reips, 2008; Musch, Bröder, and Klauer, 2001; Taylor, 2000; Tuten, Urban, and Bosnjak, 2000). Arguments in favor of web surveys emphasize cost benefits, the speed of data collection in large numbers, the flexibility of questionnaire design, and the potential to reach respondents across national borders, enabling multi-country, multilingual, and quasi-global homogenized surveys. Arguments against web surveys name survey errors common to all surveys, such as errors related to sampling, non-coverage, non-response and measurement (e.g. Dillman and Bowker, 2001). In the case of CVWS, the resulting sample is not obtained randomly, the coverage is lower among groups without access to the Internet (coverage error) and the sample only includes web visitors who respond to the questionnaire (non-response error). As a result, researchers have tested the quality of web surveys and are developing ways to improve them. The most common procedure is to test data by benchmarking them against data from the labor market; or by demonstrating the ability to empirically corroborate theoretical models. Pedraza, Tijdens, Bustillo and Steinmetz (2010) show that estimates obtained from a standard wage regression using the Spanish WI sample are comparable to those obtained from the Spanish Structure of Earnings Surveys. Bustillo and Pedraza (2010) empirically confirm a theoretical job insecurity model for five European countries using WI web survey data. The researchers further confirm that Internet activity captures socioeconomic processes in real time with no interviewer effect. Askitas and Zimmermann (2011a) use Internet search data to document how the recent economic crisis has affected health; Askitas and Zimmermann (2011b) show that Internet search intensity captures a comprehensive view of the housing market and the data enables the detection of mortgage delinquencies; Choi and Variant (2011) use search engines to forecast economic indicators like automobile sales, unemployment claims, travel destinations and consumer confidence.

In order to improve the representativeness of web surveys, two approaches have been followed (Couper and Miller, 2009). First, the "design-based" approach attempts to build a probability web survey by applying other modes for sampling (e.g. running a paper survey targeted at groups not presented in the sample), recruitment, or by providing Internet access to those individuals without it (De Leeuw, 2008; Scherpenzeel and Das, 2010). These approaches are associated with higher costs. In Spain, the provider of the WI website used recruiting, marketing, and incentive schemes to increase the participation of underrepresented groups (e.g. women). Since the WI data are collected on a voluntary basis, design-based measures are helpful in mitigating certain biases (e.g. gender bias) and in increasing the overall representativeness of the Spanish WI sample. Second, the "model-based" approach attempts to correct the bias of web surveys by applying weighting techniques (e.g. Bethlehem and Stoop, 2007; Lee and Valliant, 2009; Loosvedt and Sonck, 2008; Schonlau, Soest, Kapteyn and Couper, 2009). This approach was proven effective in the analysis based on WI data (Pedraza Tijdens, Bustillo and Steinmetz, 2010). 
Empirical research based on web data is receiving increasing attention in economic literature. In this paper, we test the quality of data obtained from web surveys by benchmarking it with a representative sample of the Spanish population. We construct propensity score weights to correct the sample by using the Spanish Labor Force Surveys based on gender, education, age cohorts, and region categories. In the analysis, we present descriptive statistics (Section 4) and then we show the quality of data in a regression framework (Section 5). Ultimately, we compare our estimates with findings presented in the SWB literature to further demonstrate the scientific validity of the WI sample. In the conclusion, we outline future research possibilities and encourage researchers to take advantage of exploring data collected from alternative sources.

\section{An overview of SWB literature}

Economists have had a long-standing preference for studying revealed preferences, i.e., looking at individuals' decisions and choices rather than at preferences reported in surveys. However, behavioral economists have shown that individuals often make irrational decisions and their choices do not align with their true preferences. Thus, it is not surprising that the research of subjectively reported measures has been receiving attention over the last decade. Kahneman and Krueger (2006) demonstrate that the validity of SWB can be assessed, in part, by identifying their correlations with other characteristics of individuals. Many studies conclude that although subject to many caveats, SWB measures complement traditional welfare analyses and their findings can be taken into consideration when formulating economic policy (Layard, 2005). The research based on individual survey data examines different aspects of reported SWB and a general consensus has been established in some variables (e.g. Frey and Stutzer, 2002). It has been found that the reported levels of life-satisfaction are higher among married, more educated, healthy and religious individuals, as well as those with higher income and low blood pressure. In contrast, lower satisfaction is reported by the disabled, newly divorced, people in their mid-40s, the unemployed, ethnic minorities and those with lower income. An important finding is that money can in fact buy happiness, but the effect in absolute terms is small relative to one's situation with regard to marriage, divorce or unemployment. Additionally, economists show a U-shaped relationship of reported life-satisfaction with age. ${ }^{4}$ The literature further documents the importance of social contacts such as active participation in civic organizations, involvement in religion and the role of physiological measures, such as temperament, personality and depression (Diener, Lucas, Smith and Suh, 1999; Blachflower, 2008).

In the following, we review literature that explores the role of working conditions on SWB. Face-to-face surveys are limited in the number of observations per country. Therefore, researchers typically perform SWB analysis by pooling the observations of more countries. Oswald (2002) uses 1996 Eurobarometer surveys to demonstrate the effect of some important job characteristics, such as occupation, hours of work, job security, trade union affiliation and commuting time to work on job satisfaction in European countries. Peiró (2006) uses the 1996 World Value Survey to examine the relationships between socio-economic conditions and satisfaction with life in 15 countries. Despite the large cultural differences that exist between countries, Peiró confirms a robust relationship between SWB and age, marital status, and health. Employment status and the type of contract are included in the analysis. The authors also studied country-specific regressions that are less statistically convincing. Estimates

${ }^{4}$ Blachflower and Oswald (2008) find a robust U-shape in seventy-two countries. 
for Spain suggest that unemployed and part-time workers report lower levels of satisfaction and self-employed workers report higher satisfaction levels relative to fulltime workers. Spain is also included in the analysis by Drobnic, Beham and Prag (2010) who studied the link between different parameters of job quality and overall life satisfaction using the 2003 European Quality of Life Survey. Job insecurity and having a boring job are identified as major negative factors to life satisfaction. In general, the authors discovered that the impact of working conditions on life satisfaction is stronger in Southern and Eastern European countries relative to Western European countries. The estimates from separate country regressions show low statistical power to corroborate the general findings, mainly due to the small sample size. The relationship between workers' job satisfaction and workplace practices in Europe is explored in Bauer (2004). Based on the 2000 European Survey on Working Conditions, the author shows that flexible working arrangements are associated with higher job satisfaction and that workers value autonomy in performing their tasks and the opportunity to participate in decision-making. Ferrer-i-Carbonell and Praag (2006) explore the relationship between the type of contract and individual job satisfaction in the Netherlands and Spain. They use the European Community Household Panel from 1995-2001 to confirm that for Spanish workers, not having a permanent contract has a considerable negative impact on their job satisfaction, while the effect is much smaller in the Netherlands. These authors explain that their findings reflect the different levels of uncertainty associated with each type of contract in the two countries. A fixed-term contract in Spain may be a low quality contract compared to the Netherlands and it takes longer before it turns into a permanent job. This result is supported by Origo and Pagani (2009), who use the 2001 Eurobarometer surveys to show that in European countries, what matters for job satisfaction is not the type of contract, but mainly perceived job security.

In 1999, the Spanish Ministry of Labor and Social Affairs initiated the Quality of Working Life Survey (ECTV). ${ }^{5}$ It is an annual representative survey of Spanish workers that collects information on labor relations and the quality of life in the workplace. The survey provides a reasonable sample size, but does not permit longitudinal analysis. Namkee (2007) uses the ECVT from 1999-2004 to examine the relationship between job characteristics and workers' satisfaction with life and job. The analysis concentrates on the effect of intangible job characteristics such as work flexibility, independence, social contacts, trust in superiors, and a pleasant and low-stress work environment. Namkee evaluates that the combined effect of intangible job characteristics on lifesatisfaction is larger than doubling an individual's wage. Burón (2009) estimates job satisfaction regression using the 2004 ECVT to identify the negative effect of longworking hours, long commutes, over-qualification, and previous unemployment experience. He finds that job stability, good relationships at the workplace and a pleasant working environment are positively related to job satisfaction.

In general, the empirical evidence on SWB confirms that the quality of working conditions is important. In this paper, we contribute to the literature by exploring data obtained from a CVWS, testing whether the above findings are corroborated by the web survey.

\footnotetext{
${ }^{5}$ For more details, see http://www.empleo.gob.es/estadisticas/ecvt/welcome.htm
} 


\section{Data and summary statistics}

\subsection{WageIndicator web-surveys}

The analysis is based on data collected from a web survey posted at www.tusalario.es the Spanish website of the WageIndicator project. The questionnaire is uploaded on the website and the survey is answered in a process of non-controlled self-selection, whereby some individuals complete the questionnaire and others do not. WI websites attract large numbers of web-visitors, primarily because of the Salary Check, providing up-to-date information about the real wages earned in a wide range of occupations. Every web-visitor is invited to complete a web-survey, which takes 10 to 20 minutes. The survey has detailed questions about earnings, benefits, working conditions and employment contracts, as well as questions about education, occupation, industry, and household characteristics. Most importantly, the survey includes questions inquiring about the level of satisfaction in different domains such as life, job, and the combination of family and work. Detailed information about the WI project, the web survey characteristics, the questionnaire and a description of variables can be found in Tijdens, Zijl, Williams, Klaveren, Steinmetz (2010). In this paper, we make use of information on more than 20,000 individuals who completed the questionnaire between 2005 and 2011. The description of questions used in the analysis together with descriptive statistics is provided in Table 5. In order to correct the representativeness of the WI sample, we calculate propensity score adjustment weights following Pedraza, Tijdens, Bustillo and Steinmetz (2010). The weights are calculated based on gender, age, education and Spanish regions using Spanish Labor Force Surveys as the reference sample.

\subsection{The European Social Survey}

In order to test the data quality of the WI sample for SWB analysis, we make use of the European Social Survey (2013) (ESS), a traditional probability survey ${ }^{6}$. The ESS interviews all respondents on a face-to-face basis ${ }^{7}$ and is representative of the Spanish population. The ESS cumulative data file includes information from four waves conducted between 2004 and 2011. Importantly, the survey includes relevant information on individual and household characteristics, work conditions and SWB. The desirable time coverage and representativeness makes the ESS a suitable dataset to compare with the WI sample. ESS is commonly used to study life-satisfaction in the European context (e.g. Caporale, Georgellis, Tsitsianis and Ping, 2009; Clark and Senik, 2010; Betz and Simpson, 2013) or in Spain (e.g. Cunado and de Gracia, 2012).

\subsection{Summary statistics}

Table 1 shows the time frame of the survey data used in the analysis. The samples are limited to employed individuals 15 to 64 years old and to observations with complete information. As discussed above, the main advantage of the WI sample is that it is being collected continuously and in substantially larger numbers relative to traditional surveys like the ESS (there are 3,445 observations in the ESS compared to 20,095 in the WI sample). The sample characteristics of both surveys are presented in Table 2. In Column 2, we present the WI sample after implementing propensity score adjustment weights while Column 3 shows statistics of the WI sample without weights. If the ESS sample is taken as representative of the Spanish population, then highly educated and younger participants are overrepresented in the WI sample. This is because the WI website is

\footnotetext{
${ }^{6}$ The ESS 1-5 cumulative file provided by the Norwegian Social Science Data Services, Norway - Data Archive and distributor of ESS data.

${ }^{7}$ Based on an ESS documentation report, the average response rate in Spain was about 65\% in all waves.
} 
mostly visited by young workers with higher levels of education who are seeking information about wages. Naturally, some discrepancies between the WI and ESS samples can be attributed to the lower amount of Internet accessibility among older people. Importantly, it is observed that the weights are effective in moving the estimated mean of the WI sample closer to that of the population. Some sample characteristics like the share of females or the share of foreign-born workers are very similar in both samples. In contrast, self-employed workers are largely underrepresented in the WI sample. The comparison further reveals that respondents in the WI sample report a substantially lower satisfaction with life. It is suggested by surveyors that information provided in self-administered questionnaires is more reliable than interviewer-assisted surveys, especially when questions intrude on sensitive or private matters (notice also the differences in reported general health status). Table 2 reveals that the WI sample differs from the ESS in several dimensions. Thus, the lower reported levels of lifesatisfaction in the WI sample can be caused by the sample composition. In the next section, we contrast the quality of the WI sample with that of the ESS in the lifesatisfaction regression framework.

\section{Estimation and results}

\subsection{A comparison of the WI and ESS samples in the life-satisfaction model}

The measure of individual well-being used here is the answer to the question, "How satisfied are you with life as a whole?" Possible answers in both the ESS and WI surveys are presented on a ten-point scale from 1 to 10 where 1 is "Not satisfied at all" and 10 "completely satisfied". 8 In the analysis, we follow the literature regarding the dependent variable definition, model specifications and estimation methodologies. Given the nature of the dependent variable, the ordered logit model is the appropriate estimation technique. Ferrer-i-Carbonell and Frijters (2004) show that OLS estimates when treating the aggregated answers as a continuous variable are very similar. We estimate the life-satisfaction model including generally accepted determinants from well-being literature that are available in both surveys. Table 3 presents estimates for the ESS sample (Column 1), for the WI sample with weights (Column 2) and without weights (Column 3). In general, the estimates are consistent with the findings presented in the literature (e.g. Frey and Stutzer, 2002). The most important factors are marital status, age, and income, which all are identified to have a significant relationship and estimated with the expected sign in both samples. The income variable is a prominent variable in the life-satisfaction models and a positive association is found between the two variables. The measure of income variable is not compatible between surveys. Therefore, marginal effects cannot be compared. ${ }^{9}$ We identify a particularly strong impact of health variables, with decreased health status leading to a sharp drop in wellbeing. Yet few differences are observed between the ESS and WI samples. The estimate on dummy variables for divorced individuals is negative in the ESS sample and is not confirmed in the WI sample. While the representativeness of the WI sample can be a concern, it is shown that estimates from the WI sample exhibit very similar patterns to the estimates from the ESS sample. Furthermore, estimates from the WI sample with

\footnotetext{
${ }^{8}$ The scale in the ESS ranges from 0 to 10 , and therefore zeros are replaced with ones ( $0.6 \%$ of the cases). This change does not alter the main findings.

${ }^{9}$ Information on net monthly income is provided at the household level in the ESS, and is banded into eleven categories. In the regressions, we include log income calculated using the mid-point of each income bracket (the same approach is adopted in Clark and Senik (2010) and Betz and Simpson (2013)). The WI sample includes information on individual gross monthly income.
} 
weights are closer to ESS estimates with the significance of estimates remaining unchanged. Therefore, in subsequent analysis, we rely on the WI sample with weights. In the next section, we continue the analysis by exploring different domains of SWB and by expanding the set of determinants that is not possible to perform with ESS data.

\subsection{SWB and the role of personal characteristics}

We conduct the analysis to achieve three goals. First, we compare the estimates on personal characteristics from the WI sample to the findings generally accepted by literature. Second, we discuss the stability of estimates when the set of objective working conditions and the subjective evaluations of work are included in the model. Finally, we discuss the role of individual characteristics in the different domains of well-being such as satisfaction with life, satisfaction with job, and satisfaction with the family and work balance. We aim to provide new conclusions on job related variables not widely presented in the SWB literature. To demonstrate the importance of working conditions, we first estimate a baseline model including standard personal and family characteristics and then we expand the model to include the wide spectrum of working conditions. In the baseline specification, we include gender, education, marital status, age, health status, foreign born, self-employed, gross monthly income and the index of occupational prestige. All models include regional and year fixed effects. Table 4 presents the estimates. In the following paragraphs, we discuss the findings with respect to results commonly presented in the literature.

\section{Gender}

Regarding gender, most studies have found no difference in reported life-satisfaction (e.g. Peiró, 2006) or job satisfaction (e.g. Bauer, 2004) between men and women in European countries. Blanchflower and Oswald (2004) look at gender differences in SWB in the US and UK over a long period of time and find the convergence process by which the positive impact of women observed in the past has disappeared over time. It has been suggested that the convergence is attributed to the unforeseen consequences of anti female-discrimination policies. In our analysis, we have found no gender difference in reported life-satisfaction by gender and the result holds true when work characteristics are added to the model. An important outcome is that women are significantly less satisfied with the combination of family and work and the result is independent from job parameters. Interestingly, women report higher job satisfaction relative to men, although the difference is small. The result shows that men and women encounter different working conditions because gender difference in job satisfaction appears only when working conditions are controlled. Similarly, Burón (2009) finds that Spanish women report higher job satisfaction relative to men.

\section{Education}

Educational attainment is strongly influenced by family income and socio-economic background. There are many recent papers that analyze the relationship between educational variables and SWB. Some empirical studies document a significant positive effect of education on happiness (e.g. Di Tella, MacCulloch and Oswald, 2001; Diener et al, 1999) and others obtain a negative effect (e.g. Caporale et al, 2009). A possible explanation for negative associations is that education raises aspirations that are not fulfilled. In the case of Spain, the empirical evidence is in line with human capital literature that considers education as an investment that leads to better jobs. Cunado and de Gracia (2012) use the Spanish ESS from 2008 to show that education variables become insignificant when financial situations and current labor status are controlled in the regression. The role of education on life satisfaction is not confirmed in Peiró 
(2006)or Namkee (2007), nor in our estimates using the WI sample. The estimates on education variables in the job satisfaction equation show that the positive effect of higher education is driven by better working conditions to which higher education opens access.

\section{Marital status}

Marriage is one of the most important institutions and there are a number of studies showing the positive relationship between marriage and SWB (e.g. Dienner et al, 1999; Myers, 2003; Stack and Eshleman, 1998). Economists explain the positive effect of marriage through its effect on household income. According to Becker (1981), married individuals enjoy the benefits of household production and labor division. In addition, sociologists and psychologists emphasize the increased emotional support and relational gratification (Stutzer and Frey, 2006). Following Becker's theory, living with a working spouse conveys an additional benefit. In our analysis, people who are single form the reference category. The variables describing married, cohabiting and divorced individuals display a positive association with life-satisfaction and magnitudes change only slightly when working conditions are accounted for. The evidence indicates that persons living as couples are often happier. An alternative explanation is that the positive and persistent effect of marriage points to other beneficial factors of marriage such as emotional support and relational gratification. Marital status has not been identified to have any association with either job satisfaction or satisfaction with the family and work balance.

\section{Age}

In accordance with most studies on SWB, we identify a U-shape relationship of lifesatisfaction according to age. Younger and older people are generally more satisfied with life, while the lowest levels are reported by people in their mid-40s. The pattern is preserved and estimates change only slightly when working conditions are controlled. Yet it is observed that minimum life-satisfaction is moving towards a higher age, which indicates that older workers are employed in occupations with potentially better working conditions. The pattern for job satisfaction with respect to age shows that lowest levels are recorded for young workers. After working conditions are controlled, the workers in the 45-54 age group report the highest levels of job satisfaction. Estimates further imply that, ceteris paribus, older workers are most satisfied with the family and work balance.

\section{Health status}

Individual health status is ranked as one of the most valued aspects in people's lives (OECD, 2012). It enhances people's opportunities to participate in the labor market as well as allowing them to have good social relationships. Peiró (2006) and Caporale et al (2009) confirm a robust relationship exists between health and SWB in cross-country analyses. The WI sample includes information on self-perceived general health status. Estimates confirm that self-reported individual health status is being identified as a very strong predictor in all domains of SWB. Moreover, it is worth noting that the magnitude of health variables changes only slightly when working conditions are added to the model.

\section{Foreign born}

Migration is an opportunity for those in search of better opportunities and a better way of life. Recent studies demonstrate stronger intentions to migrate among people with lower levels of life-satisfaction (e.g. Otrachshenko and Popova, 2012). Despite migrants 
moving to new places in search of a better life, they may have false expectations about their future achievement or be confronted with a change in aspirations as their reference group changes. Identification is difficult also because migrants happy with life in migration are less prone to move back home or to another country (Mara and Landesmann, 2013). Empirical evidence is rather mixed on this issue. Our analysis suggests that foreign-born individuals in the WI sample experience higher lifesatisfaction relative to natives. However, the positive effect is not translated to other domains. Migrant workers often perform worse quality jobs than natives (e.g. working longer hours for lower wages, etc.). However, our estimates do not confirm that immigrant workers are in general less satisfied with their jobs than Spanish workers.

\section{Income and wealth}

Personal income and wealth are essential components of individual well-being. Income allows people to satisfy their needs and pursue their goals while wealth helps to sustain it over time. SWB increases with income and that is a very fundamental finding in the literature. Jobs with high pay are often characterized by better working conditions. Not surprisingly, when working conditions are included, the estimated coefficient on income variable substantially decreases. The pattern is more pronounced in the job satisfaction model where the estimate on income declines to one-third of the magnitude. Personal income is not associated with satisfaction with the family and work balance in the baseline model. Estimates from the model with working conditions imply it is more difficult to combine family and work for high-income workers. Home ownership is used as a proxy for wealth. This variable exhibits a positive correlation to life-satisfaction and satisfaction with the family and work balance.

\section{Occupational prestige}

Job prestige refers to the admiration and respect that a particular occupation holds in a given society. Occupational prestige is measured by an index with 0 being the lowest possible score and 100 being the highest and is independent of the particular individual who occupies a job. ${ }^{10}$ Estimates imply that workers employed in a prestigious occupation report higher life-satisfaction, but the effect is mitigated and disappears when work characteristics are controlled. The satisfaction with the family and work balance shows no relationship to job prestige. As expected, a robust and positive relationship is observed between occupational prestige and job satisfaction.

\section{Self-employment}

The Spanish labor market is generally characterized by a high percentage of selfemployed workers. According to the Spanish Labour Force Survey, self-employment represented 16 per cent of the total working population in Spain in 2011. Unfortunately, the number of self-employed in the WI sample is very low (less than 1 per cent). Despite their low number, the self-employed are identified to report higher satisfaction with their job relative to employed workers. The relationship between being selfemployed and SWB in other domains is not confirmed, probably due to the low sample size,

\section{Family arrangements}

Family commitments are important for the SWB of all household members. We include two dummy variables if children younger than 6 years or older than 6 years are living in a household. Estimates confirm the negative effect on life-satisfaction in the presence of older children. The negative effect on children is confirmed by several studies using a

\footnotetext{
${ }^{10}$ The index conversion into ISCO categories was created by Ganzeboom and Treiman (2003)
} 
pooled data set (e.g. Caporale et al, 2009). Angeles (2010) estimates a negative effect on life-satisfaction of those having children using a pooled observation from a British household panel survey. The results do change, however, when Angeles considers a fixed effects regression. In this case, the effects are much closer to zero and Angeles identifies positive effects for married couples. We are aware that fixed effects are usually considered necessary in this type of regression, but a fixed effects analysis is not possible with the WI sample.

Furthermore, we consider the role of the breadwinner - a person supporting a family with his or her earnings. The main household earner typically bears the greatest amount of responsibility, but also higher difficulty with balancing the family-work life. The variable captures a negative association with life-satisfaction and satisfaction with the family and work balance.

Living with parents is a Spanish phenomenon that has to do with labor market difficulties, instability and high house prices. ${ }^{11}$ Young people continue to live with their parents while in their thirties simply because they have no other choice. However, the variable indicating living with parents exhibits no associations to SWB. Finally, we note that none of the variables characterizing family arrangements presented here relate to the job satisfaction domain.

\subsection{The role of working conditions}

Having a good job provides people with the chance to fulfill their own ambitions, to develop skills and to build self-esteem. In the following paragraphs, we discuss the results obtained on a wide spectrum of job characteristics such as the type of contract, supervisory position, union membership, working time schedule, job qualification, commuting requirements, on-the-job search, job security and employment prospects. Overall, the inclusion of working conditions substantially improves the explanatory power of the models and the R-squared increases the most in the job satisfaction model.

\section{The type of contract}

The Spanish labor market is characterized by a large share of workers employed on fixed-term contracts. In contrast to permanent contracts, fixed-term contracts offer no severance pay, low benefits and wages, little human capital accumulation and high turnover. Having a permanent contract has been an aspiration of many, particularly of young workers below 40 . While most workers enter the labor force with fixed-term contracts, these are not necessarily a stepping stone into a permanent contract. Ferrer-iCarbonell and Praag (2006) use the fixed effect regression to find that Spanish workers with a permanent contract report higher job satisfaction. Drobnic, Beham, and Präg (2010) estimate the life-satisfaction equation for the Spanish sample and they find no significant effect from the type of working contract. Similarly, our estimates imply that workers with a permanent contract do not report higher satisfaction in any domain. Permanent positions are likely to be associated with better working conditions and the positive effect on satisfaction is likely to be delivered through other channels made available by permanent contracts such as higher pay, better job prospects, recognition and regular working hours.

\section{Supervisory positions}

Supervisory positions are generally a step above the average employee and they are generally associated with higher pay, but also a higher degree of responsibility.

\footnotetext{
${ }^{11}$ In 2008, approximately 52\% of young adults aged 18-34 in Spain lived with at least one of their parents while the average in the EU is $46 \%$ (Eurostat calculations based on EU-SILC database).
} 
Estimates imply that holding a supervisory position has no association with lifesatisfaction, but provides a positive effect with regard to satisfaction with job. More importantly, it is observed that workers in supervisory positions have more difficulties with the family and work balance and report lower satisfaction in that domain.

\section{Working schedules}

Irregular working schedules are considered to negatively impact the SWB of workers. Situations in which workers spend more than 40 hours at work per week, work in the evenings or on weekends are marked by a high $U$-index ${ }^{12}$, meaning these are undesirable situations for most people. Unlike other studies, we do not compare working hours to the preferred working time (e.g. Golden and Wiens-Tuers, 2006). There is evidence to suggest that very long working hours can weaken personal health and increase stress (Spurgeon, Harrington and Cooper, 1997). Drobnic, Beham, and Präg (2010) include working hours in the quadratic form of the life-satisfaction regression and find that the point of inflection is around 41 hours per week. Our estimates clearly imply that working more than 40 hours a week and irregular working schedules display a negative association with all well-being domains. Particularly, work in the evenings or work on weekends significantly decreases the satisfaction with the family and work balance.

\section{Job qualifications}

Having a job that matches one's aspirations and competencies is a universal aspiration of most people. The lack of recognition at work may lead to a higher incidence of frustration when a worker's aspirations are not realized. One example is the situation of over-qualification, which is a common issue in the Spanish labor market. On average, one-third of the workers in the sample report they are over-qualified for their job, while 6 per cent of the workers report under-qualification. We find that, ceteris paribus, workers who report over-qualification also report significantly lower satisfaction levels with life and job. The negative impact of over-qualification on a worker's well-being can be reasoned in two ways. First, the worker has invested in education but has received neither the expected return nor the status aspired to in their company. Second, in comparative terms, workers evaluate their status in relation to their counterparts who have the same qualifications but are most likely in better positions. Estimates imply that the negative effect of job mismatch does not translate to the family and work balance.

\section{Labor unions}

Civic engagement, which refers to the activities that people perform to contribute to the functioning of society, is essential to individual well-being (OECD, 2012). One example is active participation in religious services (Kahneman and Krueger, 2006). We test whether involvement in labor affairs, measured as trade union membership, displays a positive impact. The literature suggests that the decision to join a trade union is a consequence of low job security and job dissatisfaction. This would imply that less contented workers in particular tend to join trade unions. Estimates imply that, ceteris paribus, participation in a trade union conveys a positive impact on life-satisfaction but has a negative effect on job satisfaction. Therefore, union affiliation potentially delivers a positive effect corresponding to the importance of civic engagement and a negative effect corresponding to the type of worker who is discontent with work.

\footnotetext{
${ }^{12}$ National Time Accounting is a way of measuring society's well being based on time use and its explicit form is the U-index, for "unpleasant" or "undesirable", which measures the proportion of time that an individual spends in an unpleasant state. See also Kahneman and Krueger (2006).
} 


\section{Job commuting}

People spend a considerable amount of their valuable time commuting to and from work. Traveling longer distances is chosen if it results in a financially rewarding job or in additional welfare gained from a pleasant living environment. In general, commuting time exhibits a significant negative effect on SWB (e.g. Drobnic, Beham, and Präg 2010; Burón, 2009). The literature suggests that decisions about commuting involve a tradeoff that is difficult to assess and individuals wrongly predict the cost of commuting. Our estimates imply that satisfaction with a job is not affected by commuting requirements, while the satisfaction with the family and work balance is negatively affected by long-commutes. This supports the explanation that workers are likely to agree with job commuting in order to improve their situation in the labor market, but underestimate the negative effects of commuting in other domains.

\section{On-the-job search, job insecurity and future career prospects}

Results from literature demonstrate that employment stability is desirable for workers, and significantly affects their SWB (e.g. Drobnic Beham, and Präg , 2010; Burón, 2009; Ferrer-i-Carbonell and Praag, 2006). By including variables indicating on-the-job searches, job insecurity and good career prospects, we show that employment prospects translate into different domains of SWB. Individuals who look for another job when they have a job indicate disappointment with their current employment situation, and as a result, the estimated coefficient on job search variables delivers a strong negative impact on job satisfaction. We consider a job to be insecure if a worker perceives that he or she may lose his or her job in the following year. Estimates imply that workers employed in jobs with less security exhibit a negative effect in all satisfaction domains. In contrast, a good career opportunity in one's current employment has a positive effect on all satisfaction domains. Estimates demonstrate that favorable job prospects are important determinants of satisfaction with the family and work balance.

\section{The impact of past unemployment}

Past unemployment negatively affects SWB (e.g. Clark, Georgellis and Sanfey, 2001). Unemployment places people at risk of social exclusion, poverty and deprivation. According to the unemployment equilibrium theory (Pissarides, 1992) and the theory on matching models (Pedraza, 2008), the experience of long-term unemployment is connected to a lower probability of finding a job and the erosion of human capital; it also has strong negative psychological consequences on self-esteem. It has been found that unemployed individuals feel frustrated, rejected, and left out (Layard, Nickell and Jackman, 1994). We test the hypothesis by including a variable that identifies workers who have had past experience with a long-term spell of unemployment. The estimated coefficient is not significant at the conventional level for life-satisfaction and job satisfaction domains. However, the stigma of unemployment persists in satisfaction with the family and work balance.

\subsection{Satisfaction levels by the quality of working conditions}

To illustrate the effect of factor estimates in Table 4 on different satisfaction domains, we calculate predicted satisfaction scores for a hypothetical worker. Predictions are made for a worker aged 35 with a tertiary education who is married and living with a child younger than 6 years. The left-hand bars in Figure 1 display the predicted satisfaction scores under undesirable working conditions characterized by having no permanent contract, no supervisory position, being over-qualified, having long working hours, working in the evenings, commuting longer than 90 minutes per day, experiencing job insecurity and having no career prospects at the current job. The right- 
hand bars in Figure 1 displays the predicted satisfaction scores of the same worker under desirable working conditions characterized by having a permanent contract, supervisory position, standard working hours, commuting between 30 and 90 minutes per day, having a secure job and good career prospects. The middle bars in Figure 1 shows the mean of satisfaction scores observed in the sample for the hypothetical worker.

A comparison of observed and predicted satisfaction scores demonstrates that the quality of working conditions interferes with different domains of worker's well-being. In all cases in which cumulative disadvantages exist at work, a stronger negative effect on satisfaction occurs than the overall positive effect generated by desirable working conditions. The relative variation in satisfaction scores because of different working conditions is largest in the satisfaction with jobs and lowest in the satisfaction with life.

\section{Conclusions and discussion}

The above analysis is based on data collected from a web survey in the WageIndicator project. We evaluate the quality of CVWS data in the SWB analysis of Spanish workers and prove that the propensity score adjustment weights are effective at improving the performance of the WI sample. Estimates from the WI sample exhibit remarkably similar patterns to estimates from the ESS sample. In addition, our results are consistent with literature, indicating that the SWB of nations can be replicated in CVWS samples. These findings contribute to the debate regarding web data quality, and the data reliability for empirical research.

Job quality is a multi-dimensional concept. Work is perceived not only as providing income, but for many, it may be the principal source of personal identity, mediating the sense of the contribution to society and being a valued person. Related to this, we identify several aspects of work characteristics that are particularly salient in the three domains of SWB - overall life-satisfaction, satisfaction with job, and satisfaction with the family and work balance. Our analysis provides several important results:

1. Jobs with high pay are often characterized by better working conditions. We show that the positive impact of personal income is largely diminished although does not become zero when job-related variables are added to the model. An important finding is that high-income earners exhibit less satisfaction with the family and work balance.

2. Self-reported health appears to be the most important influence on SWB, with those in very bad health reporting by far the lowest levels of SWB. This result is robust to the inclusion of working conditions in the analysis.

3. Empirical findings confirm a strong link between job insecurity and low wellbeing. Workers who deem that they will lose their job next year report lower satisfaction with life, job, and the family and work balance.

4. Conversely good career opportunities and job stability are positively correlated with satisfaction scores in all three domains.

5. Analysis suggests that certain job characteristics and working conditions such as long working hours, irregular working schedules and long work commutes have strong detrimental effects on overall worker life quality. Findings confirm that workers largely underestimate the negative effects of commuting on the quality of their life. Although satisfaction with jobs is not affected by commuting requirements, satisfaction with the family and work balance is negatively affected by long-commutes. 
6. Job characteristics, such as occupation prestige or proper skill match exhibit a positive effect on satisfaction with life, and satisfaction with job, but do not interfere with the family and work balance.

7. Past unemployment experience has a negative effect on the satisfaction with the family and work balance.

In general, findings support the theory of spillover perspectives according to which satisfaction in one domain (work) spills into other domains (life and family). Indeed, the analysis confirms this for several working variables. However, there are also domain specific determinants, like over-qualification, or trade union affiliations that affect each domain differently. Workers who report over-qualification also report significantly lower satisfaction levels with life and job, but a negative effect is not visible in the satisfaction with the family and work balance. Union affiliation is associated positively with satisfaction with life, which signifies the importance of civic engagement, while a negative association with job satisfaction corresponds to a discontent worker.

In the current context of globalization and fast change, it is advised that researchers in social sciences make use of web data that are available along with traditional data. Specifically, we encourage the use of web survey data that can be calibrated using a representative sample collected in parallel, such as the Labor Force Survey. Scholars running surveys should consider the implementation of web based methods to increase the sample size, or to expand the scope of questionnaires. Newly established web surveys can learn from the WI project that is currently operating in more than 70 countries. The WI project opens diverse research opportunities and serves as a laboratory to study economic phenomena globally. WI data are collected in large numbers, but the sample characteristics and quality need to be evaluated on a country basis. With representative sample available in parallel, WI data can be calibrated or benchmarked with other labor data. Conclusions from this paper show that CVWS can be used to study the SWB of nations. Data obtained from the WI project are suited to empirically study other topics in global labor markets. From the methodological perspective, web data can be used to study the mode effect, and the paradata of a survey can be used to improve data quality. Finally, we encourage the interaction between different types of data collection methods via multiple channels. The validity of data can be promoted by the existing multidisciplinary networking processes that are efficient in reducing data drawbacks and providing them to the scientific community (Steinmetz et al, 2012). This would be a step towards providing scholars with updated, reliable and valid global data. 


\section{Bibliography}

Angeles, L., 2010. Children and life satisfaction. Journal of happiness Studies 11, 523538.

Askitas, N., Zimmermann, K., 2011a. Detecting mortgage delinquencies. IZA Discussion Paper.

Askitas, N., Zimmermann, K., 2011b. Health and well-being in the crisis. IZA Discussion Paper.

Bauer, T.K., 2004. High performance workplace practices and job satisfaction: Evidence from Europe. IZA Discussion Paper.

Becker, G.S., 1981. Altruism in the Family and Selfishness in the Market Place. Economica 48, 1-15.

Bethlehem, J., Stoop, I., 2007. Online panels-a paradigm theft, in: The Challenges of a Changing World: Proceedings of the Fifth International Conference of the Association for Survey Computing. pp. 113-137.

Betz, W., Simpson, N.B., 2013. The Effects of International Migration on the WellBeing of Native Populations in Europe. IZA.

Blanchflower, D G, Oswald, A J, 2004. Well-being over time in Britain and the USA. Journal of Public Economics 88, 1359-1386.

Blanchflower, D G, Oswald, A J, 2008. Is well-being U-shaped over the life cycle? Social Science \& Medicine 66, 1733-1749.

Blanchflower, David G, 2008. International evidence on well-being.

Burón, C.G., 2009. Job Satisfaction and On-the-Job Search: A Theoretical and Empirical Approach. Revista de Economía Laboral 6, 35-54.

Bustillo, R.M. de, Pedraza, Pablo de, 2010. Determinants of job insecurity in five European countries. European Journal of Industrial Relations 16, 5-20.

Caporale, G.M., Georgellis, Y., Tsitsianis, N., Yin, Y.P., 2009. Income and happiness across Europe: Do reference values matter? Journal of Economic Psychology 30, $42-51$.

Clark, A., Georgellis, Y., Sanfey, P., 2001. Scarring: The psychological impact of past unemployment. Economica 68, 221-241.

Clark, A.E., Senik, C., 2010. Who compares to whom? the anatomy of income comparisons in europe. The Economic Journal 120, 573-594.

Couper, M P, 2000. Review: Web surveys: A review of issues and approaches. Public opinion quarterly 464-494. 
Couper, M. P., Miller, P. V., 2009. Web Survey Methods: Introduction. Public Opinion Quarterly 72, 831-835.

Cuñado, J., De Gracia, F.P., 2012. Does education affect happiness? Evidence for Spain. Social indicators research 108, 185-196.

De Leeuw, E.D., 2008. Choosing the method of data collection., in: de Leeuw, Edith D., Hox, J.J., Dillman, D.A. (Eds.), International Handbook of Survey Methodology. Taylor \& Francis Group/Lawrence Erlbaum Associates, New York, pp. 113-135.

Di Tella, R., MacCulloch, R.J., Oswald, Andrew J., 2001. Preferences over Inflation and Unemployment: Evidence from Surveys of Happiness. American Economic Review 91, 335 - 341.

Diener, E., Suh, E.M., Lucas, R.E., Smith, H.L., 1999. Subjective well-being: Three decades of progress. Psychological bulletin 125, 276.

Dillman, D.A., Bowker, D.K., 2000. The Web Questionnaire Challenge to Survey Methodologists. Spring.

Drobnič, S., Beham, B., Präg, P., 2010. Good job, good life? Working conditions and quality of life in Europe. Social Indicators Research 99, 205-225.

Ferrer-i-Carbonell, A., Frijters, P., 2004. How Important is Methodology for the estimates of the determinants of Happiness? The Economic Journal 114, 641-659.

Ferrer-i-Carbonell, A., Van Praag, B.M.S., 2006. Insecurity in the labor market-The impact of the type of contract on job satisfaction in Spain and the Netherlands. University of Amsterdam.

Frey, B S, Stutzer, A, 2002. What can economists learn from happiness research? Journal of Economic literature 40, 402-435.

Frey, Bruno S, Stutzer, Alois, 2010. Happiness and Public Choice. Public Choice 144, 557-573.

Fricker, R.D., Schonlau, M., 2002. Advantages and disadvantages of Internet research surveys: Evidence from the literature. Field Methods 14, 347-367.

Ganzeboom, H.B.G., Treiman, D.J., 2003. Three internationally standardised measures for comparative research on occupational status, in: Advances in Cross-National Comparison. Springer, pp. 159-193.

Golden, L., Wiens-Tuers, B., 2006. To Your Happiness? Extra Hours of Labor Supply and Worker Well-Being. Journal of Socio-Economics 35, 382-397.

Groves, R.M., 2004. Survey errors and survey costs. John Wiley \& Sons.

Honing, H., Reips, U.D., 2008. Web-based versus lab-based studies: A response to Kendall (2008). Empirical Musicology Review 3. 
Choi, H., Varian, H., 2012. Predicting the present with google trends. Economic Record 88, 2-9.

Kahneman, D., Krueger, A.B., 2006. Developments in the Measurement of Subjective Well-Being. Journal of Economic Perspectives 20, 3-24.

Layard, R, Nickell, S., Jackman, R., 1994. The unemployment crisis. Oxford University Press, Oxford.

Layard, Richard, 2005. Rethinking Public Economics: The Implications of Rivalry and Habit, in: Economics and Happiness: Framing the Analysis CN - 1059909. Oxford and New York: Oxford University Press ST - Rethinking Public Economics, pp. 147-169.

Lee, S., Valliant, R., 2009. Estimation for volunteer panel web surveys using propensity score adjustment and calibration adjustment. Sociological Methods \& Research 37, 319-343.

Loosveldt, G., Sonck, N., 2008. An evaluation of the weighting procedures for an online access panel survey, in: Survey Research Methods. pp. 93-105.

Luechinger, S., Meier, S., Stutzer, Alois, 2010. Why Does Unemployment Hurt the Employed?: Evidence from the Life Satisfaction Gap Between the Public and the Private Sector. Journal of Human Resources 45, 998 - 1045.

Mara, I., Landesmann, M., 2013. Do I stay because I am happy or am I happy because I stay? Life satisfaction in migration, and the decision to stay permanently, return and out-migrate. Norface Research Programme on Migration, Department of Economics, University College London.

Musch, J., Bröder, A., Klauer, K.C., 2001. Improving survey research on the WorldWide Web using the randomized response technique. Dimensions of Internet science 179-192.

Myers, D.G., 2003. Close relationships and quality of life., in: Kahneman, D., Diener, Edward, Schwarz, N. (Eds.), The Foundations of Hedonic Psychology. Russell Sage Foundation.

Namkee, A., 2007. Value of Intangible Job Characteristics in Workers' Job and Life Satisfaction : How much are they worth ? FEDEA.

OECD, 2012. How’s Life? Measuring well-being. OECD.

Origo, F., Pagani, L., 2009. Flexicurity and job satisfaction in Europe: The importance of perceived and actual job stability for well-being at work. Labour economics 16, 547-555.

Oswald, A., 2002. Are you happy at work? Job satisfaction and work-life balance in the US and Europe. Warwick University. 
Pedraza, Pablo de, 2008. Labour Market Matching Efficiency in the Czech Republic Transition. William Davidson Institute Working Paper.

Pedraza, Pablo de, Tijdens, Kea, Bustillo, R.M. de, Steinmetz, Stephanie, 2010. A Spanish Continuous Volunteer Web Survey: Sample Bias, Weighting and Efficiency. Revista Española de Investigaciones Sociológicas 131, 109-130.

Peiró, A., 2006. Happiness, satisfaction and socio-economic conditions: Some international evidence. The Journal of Socio-Economics 35, 348-365.

Pissarides, C.A., 1992. Loss of skill during unemployment and the persistence of employment shocks. The Quarterly Journal of Economics 107, 1371-1391.

Popova, O., Otrachshenko, V., 2011. Life (Dis) Satisfaction and Decision to Migrate: Evidence from Central and Eastern Europe. Osteuropa-Institut Regensburg Working Paper.

Reips, U.D., 2006. Web-based methods, in: Eid, M., Diener, Ed (Eds.), Handbook of Multimethod Measurement in Psychology. American Psychological Association, Washington, DC, pp. 73-85.

Scherpenzeel, A., Das, J.W.M., 2010. “True”longitudinal and probability-based internet panels: Evidence from the Netherlands. Social and Behavioral Research and the Internet: Advances in Applied Methods and Research Strategies 77-103.

Schonlau, M., Van Soest, A., Kapteyn, A., Couper, M., 2009. Selection bias in web surveys and the use of propensity scores. Sociological Methods \& Research 37, 291-318.

Spurgeon, A., Harrington, J.M., Cooper, C.L., 1997. Health and safety problems associated with long working hours: a review of the current position. Occupational and Environmental Medicine 54, 367-375.

Stack, S., Eshleman, J.R., 1998. Marital status and happiness: A 17-nation study. Journal of Marriage and the Family 527-536.

Steinmetz, S, Kaczmirek, L., De Pedraza, P, Reips, U.D., Tijdens, K, Manfreda, K.L., Rowland, L., Serrano, F., Vidakovic, M., Vogel, C., 2012. WEBDATANET: A Network on Web-based Data Collection, Methodological Challenges, Solutions, and Implementation (Supplement). International Journal of Internet Science.

Stutzer, Alois, Frey, Bruno S, 2006. Does Marriage Make People Happy, or Do Happy People Get Married? Journal of Socio-Economics 35, 326-347.

Taylor, H., 2000. Does Internet research work? International journal of market research 42, 51-64.

Tijdens, Kea, Zijl, S. van, Williams, M.H., Klaveren, M., Steinmetz, Stephanie, 2010. Codebook and explanatory note on the WageIndicator dataset. AIAS, Amsterdam Institute for Advanced Labour Studies. 
Toharia, L., Cebrián, I., 2007. La Temporalidad en el Empleo: Atrapamiento y Trayectorias. Madrid: Ministerio de Trabajo.

Tuten, T.L., Urban, D.J., Bosnjak, M., 2000. Internet Surveys and Data Quality: A Review. Online social sciences 7. 


\section{APPENDIX}

Table 1 The number of observations in the samples

\begin{tabular}{|c|c|c|}
\hline Year & ESS & WI \\
\hline 2005 & 642 & 5508 \\
\hline 2006 & 564 & 3142 \\
\hline 2007 & 206 & 5962 \\
\hline 2008 & 1038 & 3249 \\
\hline 2009 & & 933 \\
\hline 2010 & & 847 \\
\hline 2011 & 995 & 454 \\
\hline Total & 3445 & 20095 \\
\hline
\end{tabular}

Source: The European Social Survey 2005-2011, Wage Indicator 2005-2011.

Note: The sample is limited to employed individuals aged 18-65 years.

Table 2 Descriptive statistics

\begin{tabular}{|l|c|c|c|c|c|}
\hline & ESS & & WI with PSA & WI & \\
\hline & $(1)$ & & $(2)$ & mean & s.dev \\
\hline mean & s.dev & mean & 6.79 & 1.80 \\
\hline Female & 7.36 & 1.76 & 6.77 & 0.44 & 0.50 \\
\hline Edu: Primary & 0.48 & 0.50 & 0.40 & 0.21 & 0.40 \\
\hline Edu: Secondary & 0.51 & 0.50 & 0.43 & 0.25 & 0.43 \\
\hline Edu: Tertiary & 0.23 & 0.44 & 0.24 & 0.54 & 0.50 \\
\hline Single & 0.31 & 0.46 & 0.38 & 0.53 & 0.50 \\
\hline Married & 0.61 & 0.49 & 0.55 & 0.42 & 0.49 \\
\hline Divorced & 0.07 & 0.25 & 0.06 & 0.04 & 0.20 \\
\hline Widowed & 0.02 & 0.13 & 0.01 & 0.00 & 0.06 \\
\hline Age 18-24 & 0.10 & 0.30 & 0.11 & 0.08 & 0.27 \\
\hline Age 25-34 & 0.25 & 0.43 & 0.25 & 0.53 & 0.50 \\
\hline Age 35-44 & 0.28 & 0.45 & 0.28 & 0.27 & 0.45 \\
\hline Age 45-54 & 0.23 & 0.42 & 0.25 & 0.10 & 0.31 \\
\hline Age 55-64 & 0.15 & 0.35 & 0.11 & 0.02 & 0.13 \\
\hline Health: excellent & 0.20 & 0.40 & 0.31 & 0.28 & 0.45 \\
\hline Health: good & 0.51 & 0.50 & 0.29 & 0.33 & 0.47 \\
\hline Health: poor & 0.24 & 0.43 & 0.23 & 0.24 & 0.42 \\
\hline Health: very poor & 0.06 & 0.23 & 0.16 & 0.15 & 0.35 \\
\hline Foreign-born & 0.07 & 0.25 & 0.06 & 0.07 & 0.26 \\
\hline Self-employed & 0.15 & 0.36 & 0.00 & 0.01 & 0.07 \\
\hline Log income & 7.45 & 0.58 & 7.32 & 7.37 & 0.58 \\
\hline
\end{tabular}

Source: The European Social Survey 2004-2010, Wage Indicator 2005-2011.

Note: Samples are limited to employed individuals 18-65 years old. WI with PSA in Column 2 presents the WI sample after implementing propensity score adjustment weights. In the ESS, information on net monthly income at the household level is calculated using the mid-point of each income bracket. The WI includes information on individual gross monthly income. 
Table 3 Life-satisfaction equations: a comparison of the ESS and WI surveys

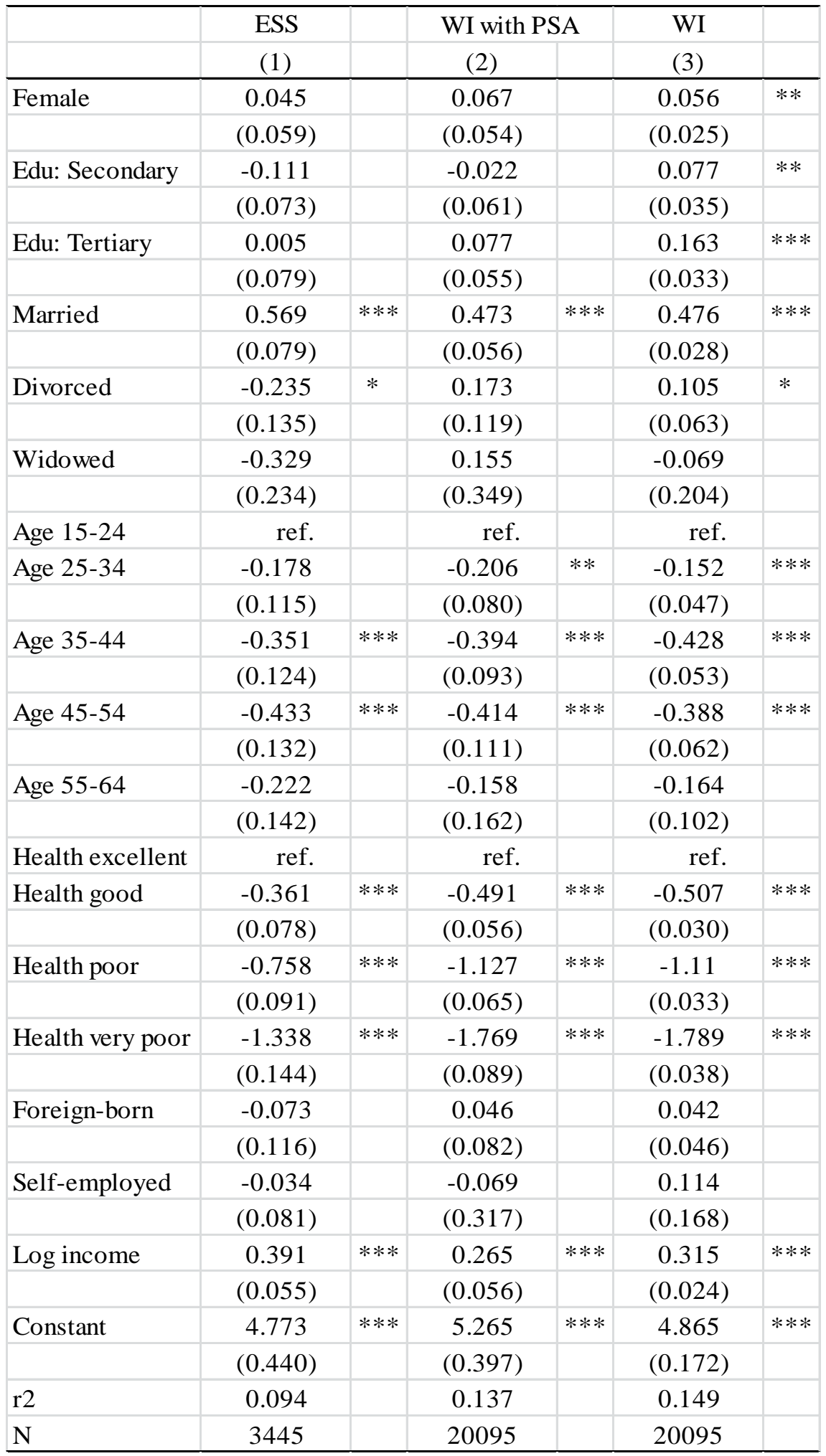

Source: European Social Survey 2004-2010, Wage Indicator 2005-2011.

Note: Dependent variable is satisfaction with life variable. Presented are OLS estimates with standard errors in parenthesis. $* / * * / * * *$ indicate significance at the $10 \% / 5 \% / 1 \%$ level. See also notes to Table 2. 
Table 4 Satisfaction equations: factors determining the quality of a job

\begin{tabular}{|c|c|c|c|c|c|c|c|c|c|c|c|c|}
\hline & \multicolumn{4}{|c|}{ Satisfaction with life } & \multicolumn{4}{|c|}{ Satisfaction with job } & \multicolumn{4}{|c|}{ Satisfaction with work and family } \\
\hline & $(1)$ & & $(2)$ & & $(3)$ & & $(4)$ & & $(5)$ & & $(6)$ & \\
\hline \multirow[t]{2}{*}{ Female } & 0.018 & & 0.035 & & 0.038 & & 0.07 & $* *$ & -0.167 & $* * *$ & -0.184 & $* * *$ \\
\hline & 0.055 & & 0.053 & & 0.037 & & 0.033 & & 0.036 & & 0.034 & \\
\hline Edu: Primary & ref. & & ref. & & ref. & & ref. & & ref. & & ref. & \\
\hline \multirow[t]{2}{*}{ Edu: Secondary } & -0.052 & & 0.004 & & -0.014 & & 0.072 & * & 0.025 & & 0.005 & \\
\hline & 0.062 & & 0.062 & & 0.042 & & 0.039 & & 0.04 & & 0.04 & \\
\hline \multirow[t]{2}{*}{ Edu: Tertiary } & 0.005 & & 0.083 & & 0.024 & & 0.13 & $* * *$ & 0.057 & & 0.037 & \\
\hline & 0.06 & & 0.066 & & 0.041 & & 0.04 & & 0.041 & & 0.042 & \\
\hline Single & ref. & & ref. & & ref. & & ref. & & ref. & & ref. & \\
\hline \multirow[t]{2}{*}{ Married } & 0.531 & $* * *$ & 0.536 & $* * *$ & 0 & & 0 & & 0.084 & & 0.102 & $*$ \\
\hline & 0.09 & & 0.085 & & 0.06 & & 0.054 & & 0.059 & & 0.057 & \\
\hline \multirow[t]{2}{*}{ Living with partner } & 0.347 & $* * *$ & 0.387 & $* * *$ & -0.057 & & -0.01 & & -0.021 & & 0.002 & \\
\hline & 0.082 & & 0.079 & & 0.057 & & 0.049 & & 0.056 & & 0.054 & \\
\hline \multirow[t]{2}{*}{ Divorced } & 0.358 & $* * *$ & 0.398 & $* * *$ & 0.062 & & 0.093 & & 0.019 & & 0.055 & \\
\hline & 0.135 & & 0.131 & & 0.086 & & 0.078 & & 0.084 & & 0.08 & \\
\hline \multirow[t]{2}{*}{ Widowed } & 0.289 & & 0.253 & & 0.177 & & 0.113 & & 0.326 & * & 0.338 & $* *$ \\
\hline & 0.373 & & 0.362 & & 0.262 & & 0.235 & & 0.174 & & 0.162 & \\
\hline Age 15-24 & ref. & & ref. & & ref. & & ref. & & ref. & & ref. & \\
\hline \multirow[t]{2}{*}{ Age 25-34 } & -0.267 & $* * *$ & -0.219 & $* * *$ & -0.127 & $* *$ & -0.015 & & -0.096 & & -0.082 & \\
\hline & 0.082 & & 0.079 & & 0.06 & & 0.048 & & 0.059 & & 0.054 & \\
\hline \multirow[t]{2}{*}{ Age 35-44 } & -0.449 & $* * *$ & -0.395 & $* * *$ & -0.12 & $*$ & 0.021 & & -0.029 & & -0.04 & \\
\hline & 0.096 & & 0.093 & & 0.068 & & 0.057 & & 0.067 & & 0.064 & \\
\hline \multirow[t]{2}{*}{ Age 45-54 } & -0.44 & $* * *$ & -0.432 & $* * *$ & -0.007 & & 0.114 & * & 0.222 & $* * *$ & 0.158 & $* *$ \\
\hline & 0.114 & & 0.113 & & 0.079 & & 0.068 & & 0.078 & & 0.076 & \\
\hline \multirow[t]{2}{*}{ Age 55-64 } & -0.213 & & -0.189 & & -0.065 & & 0.024 & & 0.334 & $* * *$ & 0.258 & $* *$ \\
\hline & 0.165 & & 0.157 & & 0.117 & & 0.109 & & 0.103 & & 0.105 & \\
\hline Health excellent & ref. & & ref. & & ref. & & ref. & & ref. & & ref. & \\
\hline \multirow[t]{2}{*}{ Health good } & -0.498 & $* * *$ & -0.523 & $* * *$ & -0.091 & $* *$ & -0.118 & $* * *$ & -0.402 & $* * *$ & -0.403 & $* * *$ \\
\hline & 0.056 & & 0.054 & & 0.041 & & 0.037 & & 0.039 & & 0.037 & \\
\hline \multirow[t]{2}{*}{ Health poor } & -1.118 & $* * *$ & -1.073 & $* * *$ & -0.386 & $* * *$ & -0.343 & $* * *$ & -0.72 & $* * *$ & -0.66 & $* * *$ \\
\hline & 0.065 & & 0.062 & & 0.045 & & 0.041 & & 0.044 & & 0.042 & \\
\hline \multirow[t]{2}{*}{ Health very poor } & -1.745 & $* * *$ & -1.641 & $* * *$ & -0.816 & $* * *$ & -0.713 & $* * *$ & -1.235 & $* * *$ & -1.147 & $* * *$ \\
\hline & 0.09 & & 0.087 & & 0.056 & & 0.054 & & 0.056 & & 0.056 & \\
\hline Foreign-born & 0.147 & $*$ & 0.191 & $* *$ & 0.044 & & 0.046 & & -0.032 & & 0.054 & \\
\hline & 0.085 & & 0.083 & & 0.068 & & 0.063 & & 0.057 & & 0.057 & \\
\hline Self-employed & -0.133 & & -0.079 & & 0.594 & $* * *$ & 0.338 & $*$ & -0.122 & & -0.237 & \\
\hline & 0.32 & & 0.342 & & 0.154 & & 0.194 & & 0.187 & & 0.214 & \\
\hline Occupation prestige & 0.006 & $* * *$ & 0.003 & & 0.008 & $* * *$ & 0.004 & $* * *$ & 0.001 & & 0 & \\
\hline & 0.002 & & 0.002 & & 0.001 & & 0.001 & & 0.001 & & 0.001 & \\
\hline Log personal income & 0.248 & $* * *$ & 0.127 & $* *$ & 0.264 & $* * *$ & 0.085 & $* *$ & -0.035 & & -0.068 & $*$ \\
\hline & 0.058 & & 0.059 & & 0.038 & & 0.037 & & 0.036 & & 0.037 & \\
\hline Main household earner & -0.12 & $* *$ & -0.123 & $* *$ & 0.023 & & 0.02 & & -0.087 & $* *$ & -0.062 & $*$ \\
\hline & 0.058 & & 0.055 & & 0.04 & & 0.035 & & 0.036 & & 0.034 & \\
\hline Lives with child aged $0-5 y$ & 0.071 & & 0.047 & & 0.025 & & 0.02 & & -0.089 & $* *$ & -0.113 & $* * *$ \\
\hline & 0.056 & & 0.055 & & 0.046 & & 0.041 & & 0.04 & & 0.04 & \\
\hline Lives with child aged 6-17y & -0.107 & & -0.123 & $*$ & 0.013 & & -0.019 & & -0.037 & & -0.05 & \\
\hline & 0.069 & & 0.065 & & 0.045 & & 0.04 & & 0.046 & & 0.044 & \\
\hline House owner & 0.319 & $* * *$ & 0.289 & $* * *$ & 0.079 & $*$ & 0.056 & & 0.18 & $* * *$ & 0.151 & $* * *$ \\
\hline & 0.065 & & 0.061 & & 0.043 & & 0.038 & & 0.04 & & 0.039 & \\
\hline Lives with parents & -0.116 & & -0.072 & & 0.008 & & 0.032 & & -0.085 & & -0.04 & \\
\hline & 0.079 & & 0.076 & & 0.052 & & 0.046 & & 0.054 & & 0.053 & \\
\hline
\end{tabular}


Table 4 continued

\begin{tabular}{|c|c|c|c|c|c|c|c|c|c|c|c|c|}
\hline & (1) & & $(2)$ & & (3) & & $(4)$ & & (5) & & $(6)$ & \\
\hline \multirow[t]{2}{*}{ Permanent contract } & & & -0.041 & & & & -0.159 & $* * *$ & & & -0.054 & \\
\hline & & & 0.055 & & & & 0.035 & & & & 0.038 & \\
\hline \multirow[t]{2}{*}{ Supervisory position } & & & 0.011 & & & & 0.084 & $* *$ & & & -0.087 & $* *$ \\
\hline & & & 0.053 & & & & 0.034 & & & & 0.035 & \\
\hline \multirow[t]{2}{*}{ Over-qualified for job } & & & -0.247 & $* * *$ & & & -0.263 & $* * *$ & & & -0.033 & \\
\hline & & & 0.053 & & & & 0.032 & & & & 0.034 & \\
\hline \multirow[t]{2}{*}{ Member of trade union } & & & 0.114 & $* *$ & & & -0.061 & $*$ & & & -0.029 & \\
\hline & & & 0.057 & & & & 0.036 & & & & 0.038 & \\
\hline \multirow[t]{2}{*}{ Working hours $>40$} & & & -0.246 & $* * *$ & & & -0.095 & $* *$ & & & -0.264 & $* * *$ \\
\hline & & & 0.07 & & & & 0.044 & & & & 0.045 & \\
\hline \multirow[t]{2}{*}{ Works in night } & & & -0.1 & $* *$ & & & -0.053 & & & & -0.321 & $* * *$ \\
\hline & & & 0.051 & & & & 0.034 & & & & 0.034 & \\
\hline \multirow[t]{2}{*}{ Works on weekend } & & & -0.08 & & & & -0.077 & $* *$ & & & -0.3 & $* * *$ \\
\hline & & & 0.06 & & & & 0.038 & & & & 0.042 & \\
\hline \multirow[t]{2}{*}{ Work: commutes $15-45 \mathrm{~min}$} & & & -0.091 & * & & & -0.007 & & & & -0.174 & $* * *$ \\
\hline & & & 0.05 & & & & 0.032 & & & & 0.034 & \\
\hline \multirow[t]{2}{*}{ Work: commutes $>45$} & & & -0.156 & * & & & 0.012 & & & & -0.364 & $* * *$ \\
\hline & & & 0.08 & & & & 0.052 & & & & 0.054 & \\
\hline \multirow[t]{2}{*}{ Looking for another job } & & & -0.375 & $* * *$ & & & -0.723 & $* * *$ & & & -0.279 & $* * *$ \\
\hline & & & 0.056 & & & & 0.034 & & & & 0.035 & \\
\hline \multirow[t]{2}{*}{ Good career opportunities } & & & 0.626 & $* * *$ & & & 0.744 & $* * *$ & & & 0.288 & $* * *$ \\
\hline & & & 0.055 & & & & 0.037 & & & & 0.039 & \\
\hline \multirow[t]{2}{*}{ Job is insecure } & & & -0.475 & $* * *$ & & & -0.347 & $* * *$ & & & -0.102 & * \\
\hline & & & 0.088 & & & & 0.053 & & & & 0.057 & \\
\hline \multirow[t]{2}{*}{ Past unempl. experience } & & & -0.059 & & & & -0.069 & & & & -0.111 & $* *$ \\
\hline & & & 0.081 & & & & 0.048 & & & & 0.055 & \\
\hline \multirow[t]{2}{*}{ Constant } & 5.042 & $* * *$ & 6.326 & $* * *$ & 0.953 & $* * *$ & 2.63 & $* * *$ & 3.713 & $* * *$ & 4.648 & $* * *$ \\
\hline & 0.419 & & 0.426 & & 0.28 & & 0.268 & & 0.25 & & 0.26 & \\
\hline r2 & 0.149 & & 0.197 & & 0.102 & & 0.261 & & 0.148 & & 0.215 & \\
\hline $\mathrm{N}$ & 20095 & & 20095 & & 20095 & & 20095 & & 20095 & & 20095 & \\
\hline
\end{tabular}

Source: Wage Indicator 2005-2011.

Note: Presented are OLS estimates. * / ** / *** indicate significance at the $10 \%$ / 5\% / 1\% level. Samples are limited to employed individuals 15-65 years old. 
Table 5: Variable Definition

\begin{tabular}{|c|c|c|}
\hline Variable name & Definition & Mean \\
\hline Satisfaction with life & $\begin{array}{l}\text { Satisfaction with life as-a-whole is measured on an ordinal } 10 \text {-point } \\
\text { scale. A higher value means that a person currently feels more } \\
\text { satisfied. }\end{array}$ & 6.73 \\
\hline Satisfaction with job & $\begin{array}{l}\text { Measured on an ordinal 5-point scale from 'highly dissatisfied' (1) to } \\
\text { 'highly satisfied' (5). A higher value means that a person currently } \\
\text { feels more satisfied. }\end{array}$ & 2.99 \\
\hline $\begin{array}{l}\text { Satisfaction with the } \\
\text { combination of family and work }\end{array}$ & $\begin{array}{l}\text { Measured on an ordinal 5-point scale from 'highly dissatisfied' (1) to } \\
\text { 'highly satisfied' (5). A higher value means that a person currently } \\
\text { feels more satisfied. }\end{array}$ & 3.19 \\
\hline Female & Female $=1$, male $=0$ & 0.41 \\
\hline Edu: primary & $\begin{array}{l}\text { (International Standard Classification of Education } 0-2 \text { ) }=1 \text {, } \\
\text { otherwise }=0 \text { (reference) }\end{array}$ & 0.39 \\
\hline Edu: secondary & $($ ISCED 3-4) $=1$, otherwise $=0$ & 0.23 \\
\hline Edu: tertiary & $($ ISCED 5-6) $=1$, otherwise $=0$ & 0.38 \\
\hline Single & $\begin{array}{l}\text { Never married and not living with a partner }=1 \text {, otherwise }=0 \\
\text { (reference) }\end{array}$ & 0.41 \\
\hline Married & Married $=1$, otherwise $=0$ & 0.53 \\
\hline Living with partner & Never married and living with a partner $=1$, otherwise $=0$ & 0.13 \\
\hline Divorced & Divorced $=1$, otherwise $=0$ & 0.05 \\
\hline Widowed & Widowed $=1$, otherwise $=0$ & 0.01 \\
\hline Age $15-24$ & Age of respondent $15-24=1$, otherwise $=0$ (reference) & 0.12 \\
\hline Age 25-34 & Age of respondent $25-34=1$, otherwise $=0$ & 0.29 \\
\hline Age 35-44 & Age of respondent $35-44=1$, otherwise $=0$ & 0.30 \\
\hline Age 45-54 & Age of respondent $45-54=1$, otherwise $=0$ & 0.22 \\
\hline Age 55-64 & Age of respondent 55-64 $=1$, otherwise $=0$ & 0.08 \\
\hline Health status & $\begin{array}{l}\text { Satisfaction with health is measured on an ordinal 4-point scale from } \\
\text { 'highly dissatisfied' (1) to 'highly satisfied' (4). A higher value means } \\
\text { that a person currently feels more satisfied. }\end{array}$ & 2.77 \\
\hline Foreign-born & Respondent was not born in Spain $=1$, otherwise $=0$ & 0.06 \\
\hline Self-employed & Respondent is self-employed $=1$, otherwise $=0$ & 0.01 \\
\hline Occupation prestige & $\begin{array}{l}\text { Occupational prestige is measured by index with } 0 \text { being the lowest } \\
\text { possible score to } 100 \text { being the highest. The index conversion into } \\
\text { ISCO categories is created by Ganzeboom and Treiman (2006) }\end{array}$ & 43.08 \\
\hline Personal income & $\begin{array}{l}\text { Logarithm of gross monthly income in EUR (it include bonuses, if } \\
\text { these were received in the last wage) }\end{array}$ & 7.31 \\
\hline Child 0 - 5 years & Child below age 6 lives in the household $=1$, otherwise $=0$ & 0.14 \\
\hline Child 6-17 years & Child older than 5 lives in the household $=1$, otherwise $=0$ & 0.24 \\
\hline House owner & House is owned $=1$, otherwise $=0$ & 0.78 \\
\hline Main household earner & Contributes most to household income and not single $=1$, otherwise $=0$ & 0.50 \\
\hline Lives with parents & Lives with parents $=1$, otherwise $=0$ & 0.21 \\
\hline Permanent Contract & Respondent has permanent employment contract $=1$, otherwise $=0$ & 0.78 \\
\hline Supervisor & $=$ Respondent has supervisory position $=1$, otherwise $=0$ & 0.39 \\
\hline Over-qualified for job & Respondent is overqualified for the job $=1$, otherwise $=0$ & 0.32 \\
\hline Member of trade union & Member of a trade union $=1$, otherwise $=0$ & 0.37 \\
\hline Hours of Work & $\begin{array}{l}\text { The contractual hours for a worker in dependent employment. Works } \\
\text { more than } 40 \text { hours per week }=1 \text {, otherwise }=0 \text {. }\end{array}$ & 0.15 \\
\hline Work in the evening & Respondent works regularly in the evenings $=1$, otherwise $=0$ & 0.60 \\
\hline Work on weekends & Respondent works regularly on Saturdays or Sundays $=1$, otherwise $=0$ & 0.26 \\
\hline Work commutes $0-15 \mathrm{~min}$ & Commuting $0-15 \min$ one way $=1$, otherwise $=0$ & 0.43 \\
\hline Work commutes $15-45 \mathrm{~min}$ & Commuting $15-45 \min$ one way $=1$, otherwise $=0$ & 0.47 \\
\hline Work commutes $>45$ min & Commuting $45+$ min one way $=1$, otherwise $=0$ & 0.10 \\
\hline Looking for another job & $\begin{array}{l}\text { Respondent has been looking for another job in past } 4 \text { weeks }=1 \text {, } \\
\text { otherwise }=0\end{array}$ & 0.24 \\
\hline Good career opportunities & $\begin{array}{l}\text { Respondent has good career opportunities in organization=1, } \\
\text { otherwise }=0\end{array}$ & 0.21 \\
\hline Job is insecure & Job will become redundant next year $=1$, otherwise $=0$ & 0.12 \\
\hline Past unemployment experience & $\begin{array}{l}\text { Respondent was looking for the first job longer than one year }=1 \text {, } \\
\text { otherwise }=0\end{array}$ & 0.13 \\
\hline
\end{tabular}


Figure 1 Predicted satisfaction scores by the quality of working conditions

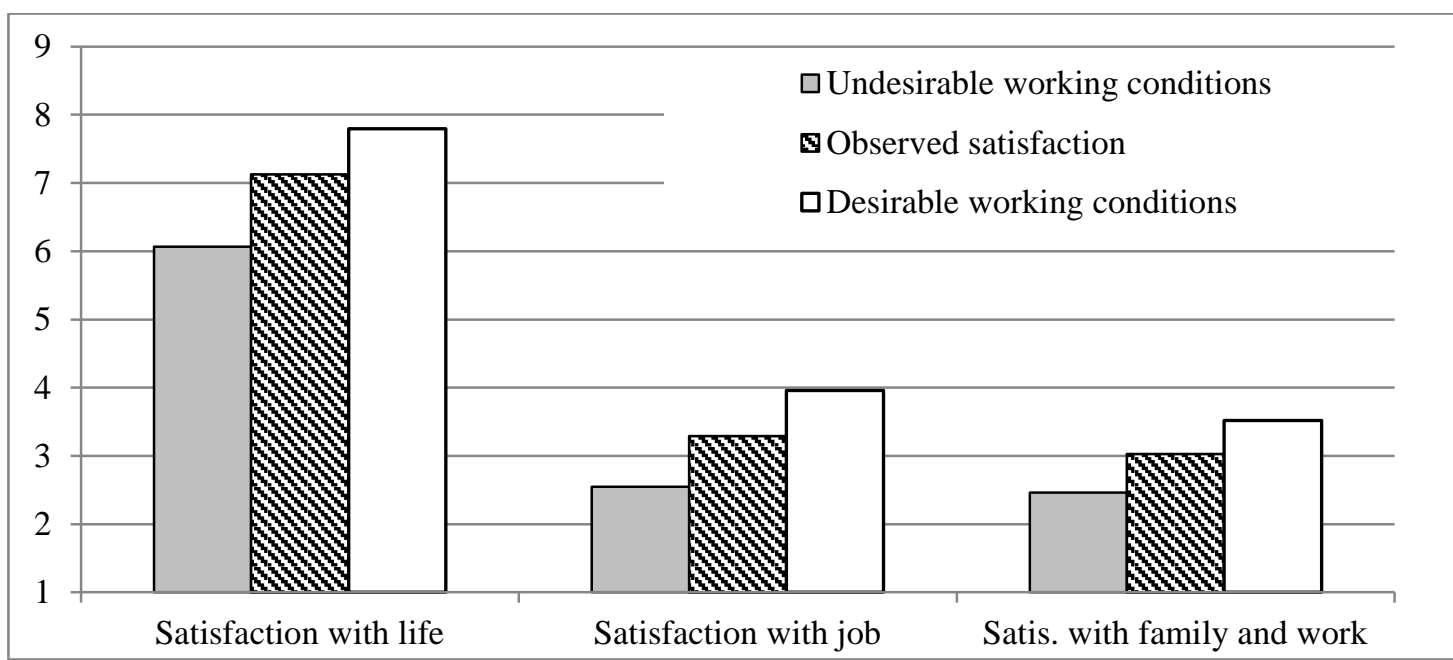

Source: Wage Indicator 2005-2011

Note: Predictions are made for a worker aged 35 with a tertiary education, married, living with a child younger than 6 years. Satisfaction with life is measured on an ordinal 10-point scale and satisfaction with job/family and work are measured on an ordinal 5-point scale. 